\title{
Ovarian Follicular Activity in Lactating Holstein Cows Supplemented with Monensin
}

\author{
S. K. Tallam, ${ }^{\star}$ T. F. Duffield, $†$ K. E. Leslie,† R. Bagg,‡ \\ P. Dick, $¥$ G. Vessie, $\ddagger$ and J. S. Walton* \\ *Department of Animal and Poultry Science \\ †Department of Population Medicine, University of Guelph, \\ Guelph, ON, Canada N1G 2W1, and \\ fElanco Animal Health, Division Eli Lilly Canada Inc., \\ Research Park Centre, Guelph, ON, Canada N1G 4T2
}

\begin{abstract}
The objective of this study was to determine effects of monensin on ovarian follicular development and reproductive performance in postpartum dairy cows. Forty-eight multiparous Holstein cows were randomly assigned to receive either a control total mixed ration ( $\mathrm{n}=24)$ or the same diet plus $22 \mathrm{mg}$ of monensin/kg ( $\mathrm{n}$ $=24$ ) from $21 \mathrm{~d}$ before anticipated calving until cows were either confirmed pregnant or were $>180 \mathrm{~d}$ postpartum. Monensin had no effect on development of the first dominant follicle postpartum or the numbers of class 1 ( 3 to $5 \mathrm{~mm}$ ), 2 (6 to $9 \mathrm{~mm}$ ), or 3 (10 to $15 \mathrm{~mm}$ ) follicles. Control cows had more class $4(>15 \mathrm{~mm})$ follicles at 10 to $13 \mathrm{~d}$ postpartum than cows in the monensin group. The first dominant follicle postpartum ovulated, regressed, or became cystic unrelated to differences between diets. However, the first ovulation postpartum occurred earlier in monensin-fed cows than in the control group ( $27.2 \pm 2.1 \mathrm{~d}$ vs. $32.4 \pm 1.5 \mathrm{~d})$, with no dietary effects on the diameter of the ovulating follicle. Similarly, treatments did not differ in the proportion of cows with 2 or 3 waves of ovarian follicular development per cycle, nor in the number of follicles of all classes during the breeding period. Times of ovulation following treatment with prostaglandin $\mathrm{F}_{2 \alpha}$ were not different between dietary groups. Pregnancy rates after timed artificial insemination were similar between diets. Supplementation with monensin resulted in a shorter postpartum interval to first ovulation but did not affect other reproductive measures in healthy, lactating dairy cows.
\end{abstract}

(Key words: dairy cow, monensin, ovarian activity, ovulation)

Abbreviation key: $\mathbf{C}=$ control treatment, $\mathbf{M}=$ monensin treatment, NEBAL = negative energy balance, PGF $=$ prostaglandin $\mathrm{F}_{2 \alpha}$ analog.

Received February 3, 2003.

Accepted July 25, 2003.

Corresponding author: J. S. Walton; e-mail: jswalton@uoguelph.ca.

\section{INTRODUCTION}

The resumption of reproductive activity following parturition is associated with changes in energy balance. Previous studies (Canfield et al., 1990; Lucy et al., 1991; Beam and Butler, 1998) have shown that there is a positive correlation between the extent and duration of negative energy balance (NEBAL) and the interval to first ovulation. In dairy cows experiencing NEBAL postpartum, there is a deficiency in the release of LH rather than FSH (Lamming et al., 1981; Beam and Butler, 1999). Thus, resumption of the normal episodic LH release necessary for preovulatory follicular development has been proposed as the key event in the return to ovarian cyclicity of cows in NEBAL (Lamming et al., 1981; Malven, 1984; Canfield and Butler, 1990; Canfield and Butler, 1991). Early resumption of ovulatory cycles has also been shown to enhance conception rate to first insemination (Thatcher and Wilcox, 1973; Lucy et al., 1992). Therefore, strategies that minimize the duration and extent of NEBAL and restore normal function of the hypothalamic-pituitary axis have the potential of enhancing resumption of ovarian cyclicity and overall reproductive performance.

Monensin sodium has been shown to modify rumen fermentation and improve digestive efficiency in beef and dairy cattle (Richardson et al., 1976; Schelling, 1984). The net impact of feeding monensin is an increase in plasma glucose concentrations (Abe et al., 1994; Duffield et al., 1998), and a decrease in plasma concentrations of free fatty acids and ketones (Sauer et al., 1989; Abe et al., 1994). Earlier studies also suggest that monensin may have some effect on pituitary and ovarian function. For example, Randel and Rhodes (1980) and Randel et al. (1982) reported significant effects of feeding monensin on pituitary and ovarian function of beef heifers. Heifers receiving dietary monensin had increased peak LH, increased duration of the LH surge, and an increase in the area under the LH curve following a GnRH challenge (Randel and Rhodes, 1980). Further evidence that monensin-induced changes in 
metabolic variables influence the hypothalamic-pituitary system was indicated by the significant increase in the duration of LH surge and area under the $\mathrm{LH}$ surge following an estradiol challenge (Randel et al., 1982). Another study investigating the effects of dietary monensin on ovarian response demonstrated that beef heifers fed monensin $(200 \mathrm{mg} / \mathrm{d})$ had greater ovarian weight, more corpora lutea, and more follicles following GnRH treatment than controls (Bushmich et al., 1980).

Studies on the effects of monensin feeding on cow productivity have shown either improved or no effect on reproductive performance. Moseley et al. (1977) reported that monensin-fed beef heifers reached puberty earlier than control heifers, but could not find significant effects on any other reproductive variables. Feeding monensin to Holstein heifers resulted in a reduction in the age at first breeding and calving without any effects on growth rate (Meinert et al., 1992). Other studies using dairy cows have reported no significant effects of monensin on conception rates (Lean et al., 1994; Hayes et al., 1996; Beckett et al., 1998; Duffield et al., 1999a).

There is a lack of detailed research data on the influence of monensin on follicular dynamics and ovarian function of the dairy cow postpartum. Given the potential benefits of monensin administration on energy efficiency and cow health, especially during the NEBAL period, it is necessary to clearly understand any secondary physiological effects on ovarian function and to evaluate the impact of monensin on fertility. The primary objective of this study was, therefore, to investigate whether monensin feeding alters follicular activity and incidence of ovulation in dairy cows during early lactation. Additionally, effects of monensin on first-service pregnancy rates, feed intake, BCS, milk production, and milk components were determined.

\section{MATERIALS AND METHODS}

Forty-eight multiparous Holstein cows were paired based on their expected calving dates and randomly assigned within pairs to receive either a control TMR (C) designed to meet NRC requirements (NRC, 1989) or the same diet including $22 \mathrm{mg}$ of monensin/kg DM (Rumensin; Provel Division, Eli Lilly Canada Inc., Guelph, ON, Canada). Cows were housed in a tie-stall barn at the Ponsonby Dairy Research Centre and individually fed. The diet ingredients for close-up and lactating cows are shown in Table 1. Diets were offered ad libitum from $21 \mathrm{~d}$ before anticipated calving date, until cows were either confirmed pregnant or were $>180$ $\mathrm{d}$ in milk. Fresh TMR was delivered twice daily at 1100 and $1500 \mathrm{~h}$. Cows were weighed and BCS (1 = very thin to 5 = very fat) were assigned weekly (Edmonson et al.,
Table 1. Ingredient composition (\% as fed) of the diets for close-up dry cows and lactating cows (M cows received these diets with $22 \mathrm{mg}$ of monensin $/ \mathrm{kg}$ of DM). ${ }^{1}$

\begin{tabular}{lcc}
\hline Ingredient & $\begin{array}{l}\text { Close-up dry } \\
\text { cow diet }\end{array}$ & $\begin{array}{l}\text { Lactating } \\
\text { cow diet }\end{array}$ \\
\hline Corn silage & 68.4 & 53.1 \\
High-moisture corn & 3.3 & 13.9 \\
Dry corn & 0.4 &... \\
Mixed haylage & 17.5 & 16.0 \\
Mixed hay & 6.5 & 4.3 \\
Soybean meal & 1.0 &. \\
Dry cow pellet & 2.3 & 12.7 \\
Lactating cow supplement &. & $\ldots$ \\
Trace mineral salt & 0.6 &. \\
\hline
\end{tabular}

${ }^{1}$ Monensin concentrations in each diet were confirmed at $22 \mathrm{mg} /$ $\mathrm{kg}$ of DM using laboratory analysis.

1989). An objective evaluation of external fat reserves at the time of body condition scoring was also measured at the rump by ultrasonography using a $5-\mathrm{MHz}$ linear array scanner (Aloka SSD500, Aloka Co. Ltd., Tokyo, Japan). Milk yields and DMI were recorded daily. Milk samples were collected once weekly at consecutive morning and evening milkings, preserved with 2bromo-2-nitropropane-1,3-diol, and analyzed for fat, protein, and lactose concentration by near infrared analysis using the Foss System 4000 (Foss Electric, Hillerød, Denmark). Daily feed samples of control and monensin TMR diets were composited weekly. The DM content of the diets was determined by drying using a $60^{\circ} \mathrm{C}$ oven for $48 \mathrm{~h}$.

To determine the effect of monensin on reproductive variables, the study was divided into 2 periods of intensive evaluation. Initially, the period from 10 to $30 \mathrm{~d}$ after calving was studied in detail. The second period of intensive study occurred at the beginning of the breeding period (50 to $80 \mathrm{~d}$ after calving). Additional measures were obtained, but with reduced intensity in the intervening period.

\section{Early Postpartum Measurements (d 10 to 30 )}

Daily blood samples were collected from the coccygeal vein for measurement of progesterone. The blood samples $(10 \mathrm{ml})$ were collected into heparinized vacutainer tubes (Beckton-Dickinson, Mississauga, ON, Canada), cooled on ice and centrifuged within $24 \mathrm{~h}$ at $1000 \times \mathrm{g}$ for $20 \mathrm{~min}$. Harvested plasma was stored at $-20^{\circ} \mathrm{C}$ until radioimmunoassay. Plasma progesterone was determined using a previously validated (Gowan and Etches, 1979) solid-phase radioimmunoassay (Coat-A-Count, Diagnostic Products, Los Angeles, CA). Plasma concentrations of BHBA, NEFA, glucose and urea were determined for plasma samples collected on d 10, 17, and 28 postpartum. Ovarian follicular activity and corpus 
luteum development was monitored daily by intrarectal examination using a real-time B-mode diagnostic ultrasound scanner equipped with a linear array $5-\mathrm{MHz}$ transducer (Aloka SSD500, Aloka Co. Ltd.). The development of follicles $\geq 3 \mathrm{~mm}$ in diameter was monitored and categorized as class 1 ( 3 to $5 \mathrm{~mm}$ ), class 2 (6 to 9 $\mathrm{mm})$, class 3 (10 to $15 \mathrm{~mm})$, or class $4(>15 \mathrm{~mm})$. The development of waves of dominant follicles was achieved by daily mapping of ultrasound images according to the methods described by Sirois and Fortune (1988). The first dominant follicles identified were classified into 3e categories: 1 ) those that ovulated; 2) those that regressed (regressive) and were replaced by subsequent dominant follicles, and 3) those that became cystic. Anovulatory follicles that were $\geq 25 \mathrm{~mm}$ in diameter and that persisted for more than $10 \mathrm{~d}$ were considered as follicular cysts. Any cows that developed clinical uterine dysfunction were treated by antibiotic infusion (Metricure, Intervet, Boxmeer, The Netherlands). Hormonal therapy (GnRH or $\mathrm{PGF}_{2 \alpha}$ analog $\left.[\mathbf{P G F}]\right)$ was not permitted before d 80 postpartum.

\section{Prebreeding Period (d 31 to 49)}

The blood sampling frequency was reduced to 3 times per week for progesterone determinations during this period. Daily ultrasound examination of ovarian follicular development was discontinued until $50 \mathrm{~d}$ postpartum.

\section{Breeding Period (d 50 to 80 )}

Daily blood samples resumed along with daily ultrasonography during the breeding period. Ovarian structures were monitored for one estrous cycle. The number of follicular waves during the estrous cycle was determined for normally cycling cows. Cows that had dominant follicles that were $\geq 25 \mathrm{~mm}$ in diameter and persisted for $>10 \mathrm{~d}$ were considered cystic. On $\mathrm{d} 7$ of the next cycle, each cow was administered $500 \mu \mathrm{g}$ of PGF (Estrumate, Schering-Plough, Pointe Claire, Quebec, Canada). Ultrasonography was performed at 4 -h intervals from $60 \mathrm{~h}$ after PGF administration to ovulation to establish the time of ovulation. Any cows that had not ovulated by $120 \mathrm{~h}$ after PGF administration were considered to have not responded to the PGF treatment. Cows were inseminated at $72 \mathrm{~h}$ after PGF injection. Pregnancy diagnosis was determined 28 to $35 \mathrm{~d}$ after AI.

\section{Postbreeding}

Cows not pregnant after the first breeding were assigned to a conventional 14-d $\mathrm{PGF}_{2 \alpha}$ analog programmed breeding protocol with pregnancy determina- tion using ultrasonography at 28 to $35 \mathrm{~d}$ post AI. Blood samples were collected from the coccygeal vein 3 times/ wk from AI until $180 \mathrm{~d}$ postpartum for measurement of progesterone as a secondary test for pregnancy. The blood samples $(10 \mathrm{ml})$ were collected into heparinized vacutainer tubes (Beckton-Dickinson, Mississauga, Ontario, Canada), cooled on ice and centrifuged within 24 $\mathrm{h}$ at $1000 \times \mathrm{g}$ for $20 \mathrm{~min}$. Harvested plasma was stored at $-20^{\circ} \mathrm{C}$ until radioimmunoassay. Cows not confirmed pregnant by $180 \mathrm{~d}$ postcalving were no longer monitored.

\section{Statistical Analyses}

Single mean comparisons were analyzed by ANOVA using the GLM procedure of SAS (SAS, Inst., Inc., Cary, NC). These included days to first ovulation, dominant follicle diameter, maximum diameter of the first dominant and ovulating follicle, duration of first estrous cycle postpartum, time of ovulation, and diameter of the ovulating follicle following administration of PGF. Treatment effects on days to first ovulation postpartum were evaluated by survival analysis using the LIFEREG and LIFETEST procedures of SAS (SAS Inst., Inc.). The data involving repeated measurements, including number of class 1 to 5 follicles, plasma progesterone concentrations, diameter of the dominant follicle from d 10 to 15 of lactation, DMI, and milk production were analyzed by repeated-measures ANOVA (Gill and Hafs, 1971) using the following model:

$$
\mathrm{Y}_{i j k}=\mu+\mathrm{Di}+\mathrm{C}(\mathrm{D})_{j}+\mathrm{T}_{k}+\mathrm{DT}_{i k}+\mathrm{e}_{i j k}
$$

where $\mathrm{Y}_{i j k}=$ dependent observation, $\mu$ = overall mean, $\mathrm{Di}=$ effect of diet, $\mathrm{T}_{k}=$ effect of time (day or week), C(D) ${ }_{j}$ $=$ effect of cow $j$ nested within diet, $\mathrm{DT}_{i k}=$ interaction of diet and time, and $\mathrm{e}_{i j k}=$ residual error. The effect of diet was tested using $\mathrm{C}(\mathrm{D})_{j}$ as the error term. Comparisons involving proportional data, including proportions of cows of 2 or 3 follicular waves, proportions with ovulatory, regressive, or cystic first dominant follicles postpartum, and percentages ovulating following PGF were evaluated using chi-square procedures.

\section{RESULTS}

The results presented are based on data from 37 cows $(\mathrm{M}, \mathrm{n}=18 ; \mathrm{C}, \mathrm{n}=19$ ) from the original number of cows assigned to the trial. The data for cows that had twins $(\mathrm{M}, \mathrm{n}=1 ; \mathrm{C}, \mathrm{n}=1)$, retained placental membranes $(\mathrm{M}$, $\mathrm{n}=1 ; \mathrm{C}, \mathrm{n}=2)$, had clinical mastitis $(\mathrm{M}, \mathrm{n}=4 ; \mathrm{C}, \mathrm{n}$ $=2$ ) and metritis, or were off feed during the early postpartum period were excluded from analyses due to possible confounding effects on reproductive variables of interest. 


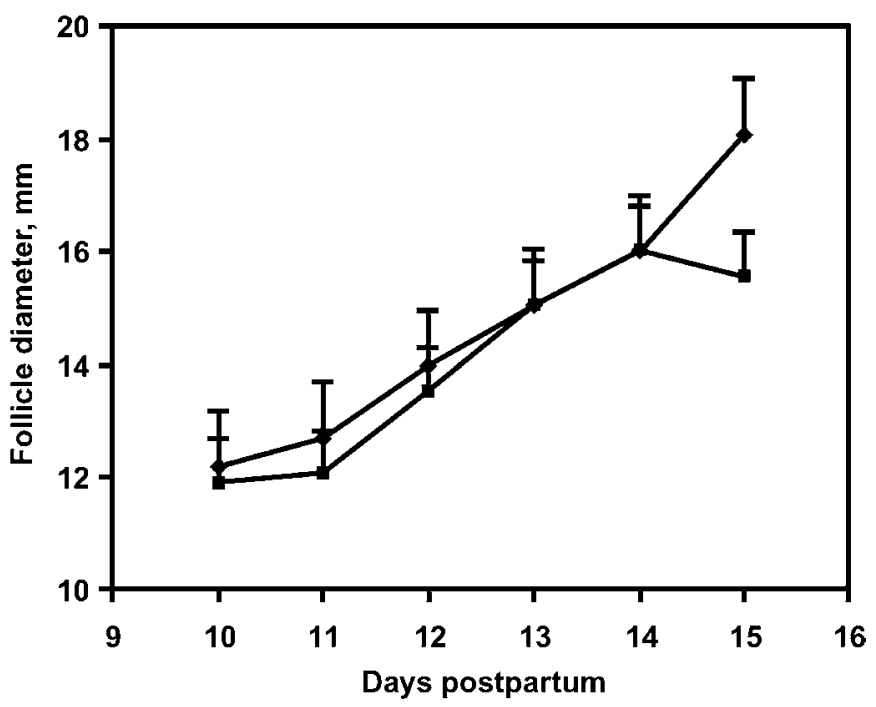

Figure 1. Mean ( $\pm \mathrm{SE})$ diameter $(\mathrm{mm})$ of first postpartum dominant follicle in cows fed monensin $(\diamond)$ or control ( $\square$ ) diets. Overall diet effects on follicle diameter were not significant $(P>0.05)$.

\section{Ovarian Follicular Dynamics}

The Postpartum Period (10 to 49 d Postpartum). Resumption of follicular development with the emergence of dominant follicles was observed in all cows by the second week of lactation. Diet had no effect $(P>$ 0.05 , diet $\times$ day, $P>0.05$ ) on the growth of the first dominant follicle postpartum (Figure 1) or the number of follicles (Figure 2) during the postpartum period. During d 10 to 13 of lactation, $\mathrm{C}$ cows had more $(0.2 \pm$ 0.1 vs. $0.1 \pm 0.1 ; P<0.05)$ class $4(>15 \mathrm{~mm})$ follicles than $\mathrm{M}$ cows. The number of follicles of all categories for $\mathrm{M}$ and $\mathrm{C}$ cows did not differ $(P>0.05)$ during the last wave of follicular growth before the first ovulation postpartum (Figure 3).

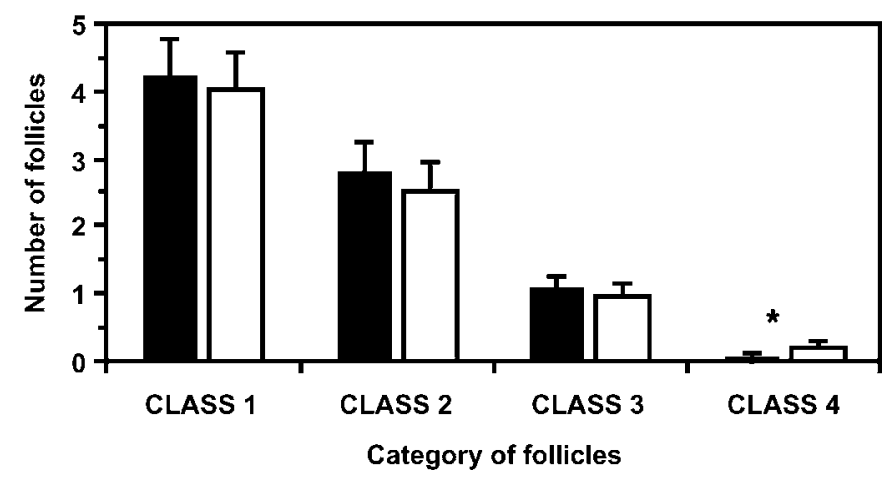

Figure 2. Mean ( \pm SE) number of class 1 to 4 follicles in monensin (匹) and control ( $\square$ ) cows during d 10 to 13 postpartum. *Monensin reduced the number of class 4 follicles $(P<0.05)$.

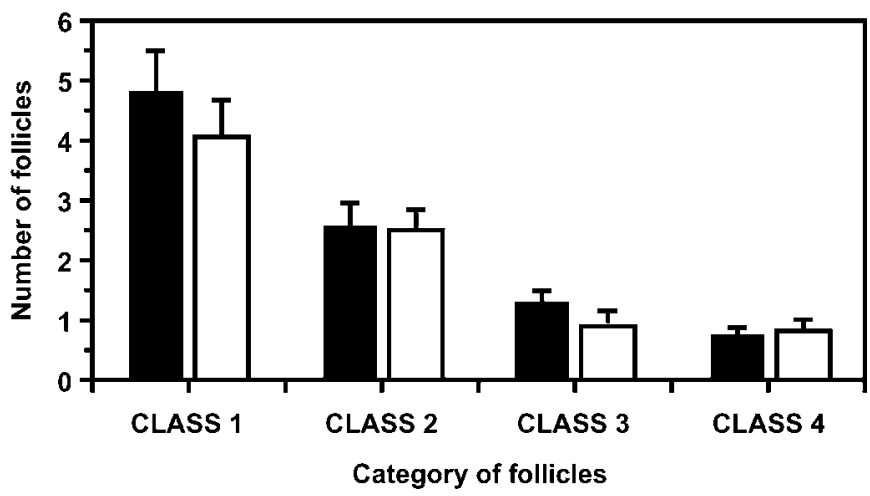

Figure 3. Mean ( \pm SE) number of class 1 to 4 follicles in cows fed monensin (ם) vs. control ( $\square$ ) cows during the last follicular wave before first postpartum ovulation. Overall effect of diet on number of follicles of all categories was not significant $(P>0.05)$.

Variables indicating postpartum ovarian function are shown in Table 2. Ovulatory, regressive, and cystic first postpartum dominant follicles were observed in both treatment groups. Diet had no effect $(P>0.05)$ on the proportion of cows with ovulatory (M, 72.2\%; C, 68.4\%), regressive (M, $11.1 \%$;, $21.1 \%)$, or cystic $(\mathrm{M}, 16.7 \%$; , $10.5 \%$ ) first dominant follicles. Maximum diameters of first postpartum dominant follicles were not different $(P>0.05)$ between $\mathrm{M}(14.6 \pm 0.9 \mathrm{~mm})$ and $\mathrm{C}(16.9 \pm .1$ $\mathrm{mm}$ ) dietary groups. Similarly, the diameters of the first ovulating follicles were not different $(P>0.05)$ between $\mathrm{M}$ and $\mathrm{C}$ groups. Diet had a significant effect on days to first ovulation with the curve for $M$ cows shifted to the left $(P<0.05$, Figure 4$)$. The first postpartum ovulation occurred $5 \mathrm{~d}$ earlier $(P<0.05)$ in the $\mathrm{M}$ cows $(27.2 \pm 0.1 \mathrm{~d})$ than in $\mathrm{C}$ cows $(32.4 \pm 0.5 \mathrm{~d})$. Diets had no effect $(P>0.05)$ on the duration of estrous cycle following the first ovulation (Table 2).

The Breeding Period (50 to $80 \mathrm{~d}$ Postpartum). Follicular development was monitored daily during the breeding period. Follicular data from one estrous cycle during this period were used to characterize follicular wave dynamics. Cows with cystic dominant follicles that persisted were excluded in the analysis of follicular waves due to the altered follicular dynamics. One cow in the $\mathrm{C}$ group however had normal follicular wave development and ovulation despite the presence of a follicular cyst. The follicular data for this cow were included in the follicular wave analysis. The results of the breeding period measurements are shown in Table 3 . During the estrous cycle, 2 or 3 waves of ovarian follicular development were observed in both treatments. Dietary groups did not differ $(P>0.05)$ in proportions of cows with $2(\mathrm{M}, 78.6 \%$ and $\mathrm{C}, 58.8 \%)$ or $3(\mathrm{M}$, $21.4 \%$ and C, $41.2 \%$ ) follicular waves per cycle. Similarly, diet had no effect on the incidence of follicular 
Table 2. Postpartum ovarian function characteristics for cows in control (C) and monensin (M; $22 \mathrm{mg} / \mathrm{kg}$ of DM) treatment groups.

\begin{tabular}{|c|c|c|}
\hline \multirow[b]{2}{*}{ Item } & \multicolumn{2}{|c|}{ Treatment } \\
\hline & M & $\mathrm{C}$ \\
\hline $\mathrm{n}$ & 18 & 19 \\
\hline \multicolumn{3}{|l|}{ Type of first dominant follicle ${ }^{1}$} \\
\hline Ovulatory, \% (n) & $72.2(13)$ & $68.4(13)$ \\
\hline Regressive, \% (n) & $11.1(2)$ & $21.1(4)$ \\
\hline Cystic, \% (n) & $16.7(3)$ & $10.5(2)$ \\
\hline Maximum diameter of first dominant follicle (DIM 10 to 13 ), $\mathrm{mm}^{2}$ & $14.6 \pm 0.9$ & $16.9 \pm 1.1$ \\
\hline Diameter of ovulating follicle, $\mathrm{mm}^{2}$ & $17.3 \pm 2.2$ & $21.0 \pm 2.0$ \\
\hline Days from calving to first ovulation ${ }^{2}$ & $27.2 \pm 2.1^{\mathrm{a}}$ & $32.4 \pm 1.5^{\mathrm{b}}$ \\
\hline Duration of first estrous cycle, $\mathrm{d}^{2}$ & $18.3 \pm 4.8$ & $20.7 \pm 4.2$ \\
\hline
\end{tabular}

\footnotetext{
a,b Treatment values different $(P<0.05)$.

${ }^{1}$ First dominant follicle postpartum either: ovulated; regressed and was replaced by another, or persisted and became cystic.

${ }^{2}$ Values are means $\pm \mathrm{SE}$.
}

cysts during the breeding period $(P>0.05)$. The numbers of follicles of all class categories (Figure 5) during the last wave of follicular development of the prebreeding estrous cycle did not differ between dietary groups $(P>0.05)$.

The proportion of cows ovulating in response to $\mathrm{PGF}$ induced luteolysis was not different $(P>0.05)$ for control $(57.9 \%)$ and monensin $(72.2 \%)$ diet groups. Diet effects on the time of ovulation relative to PGF administration (92.4 $\mathrm{h}$ for $\mathrm{M}$ and $94.8 \mathrm{~h}$ for $\mathrm{C}$ cows) and diameter of ovulating follicles were not different $(P>0.05)$. First service pregnancy rates based on ultrasonography at 28 to $35 \mathrm{~d}$ were low (M, $27.8 \%$ and C, $31.6 \%$ ) but were not different $(P>0.05)$ between treatments.

\section{Feed Intake (DMI), Milk Production, BCS, and Blood Metabolites}

The mean daily DMI, expressed as a percentage of cow live weight, increased with days postpartum $(P<$

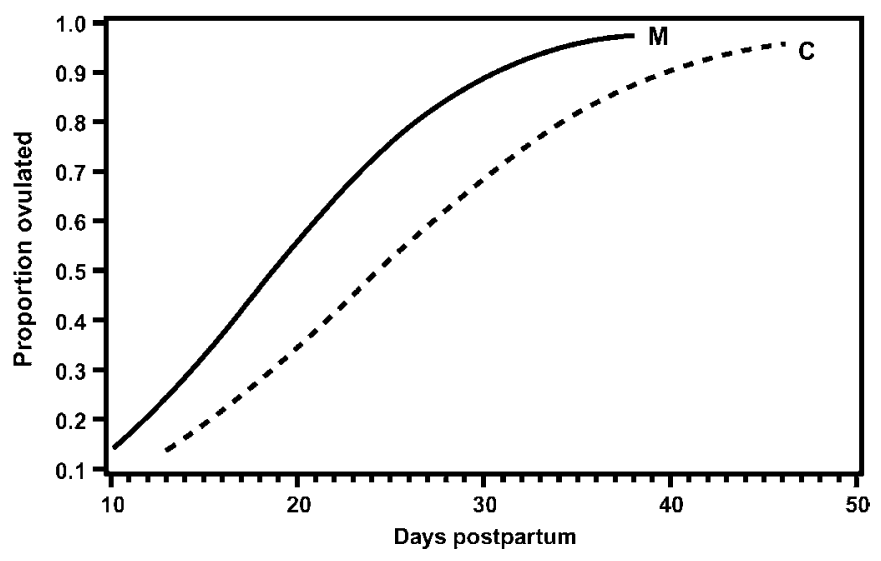

Figure 4. Survival curves for days to the first postpartum ovulation of monensin $(\mathrm{M})$ and control $(\mathrm{C})$ cows. The curve for $\mathrm{M}$ cows is shifted significantly to the left of $\mathrm{C}(P<0.05)$.
0.05, Figure 6). Although there was a general trend toward lower DMI in the cows fed monensin compared with control cows, the diet effect was not significant $(P$ $>0.05$, diet $\times$ week $P>0.05$ ).

Daily milk yield increased with weeks postpartum in all cows $(P<0.001)$. There was no diet effect on milk yield $(P>0.05$, Figure $7 \mathrm{a})$. Milk protein and fat yields were not different between the 2 groups $(P>0.05)$. There was a significant difference in milk fat concentrations (Figure 7b) of the diet groups across time $(P<$ 0.001 ), as the treated cows had initially higher, then lower, milk fat concentrations, a pattern also observed for milk protein (Figure 7c).

The effects of diet on blood metabolites during d 10, 17, and 28 of lactation are shown in Table 4. Monensin reduced $(P<0.05)$ BHBA concentrations but had no effect on plasma concentrations of glucose, NEFA, or urea $(P>0.05)$.

Body condition scores and rump fat measurements were not different at calving $(P>0.05)$, but BCS (Figure $8 \mathrm{a})$ and rump fat (Figure $8 \mathrm{~b})$ decreased $(P<0.05)$ with increasing weeks postpartum. There was a strong positive correlation $(\mathrm{r}=0.70, P<0.001)$ between BCS and rump fat during $12 \mathrm{wk}$ of lactation. Diet groups, however, did not differ $(P>0.05)$ in either rump fat or BCS during the 12 -wk period.

\section{DISCUSSION}

The current study examined the effects of sodium monensin $(22 \mathrm{mg} / \mathrm{kg}$ of $\mathrm{DM})$ on ovarian activity and reproductive performance of postpartum Holstein cows. The resumption of normal ovarian follicular development was observed in all cows by the second week of lactation, regardless of diet. In both control and monensin diets, follicular development was characterized by the growth of class $1,2,3$, and 4 follicles and the devel- 
Table 3. Measures of ovarian function during the breeding period (50 to $80 \mathrm{~d}$ postpartum) for cows in control and monensin $(22 \mathrm{mg} / \mathrm{kg}$ of DM) treatment groups.

\begin{tabular}{|c|c|c|}
\hline \multirow[b]{2}{*}{ Item } & \multicolumn{2}{|c|}{ Treatment $^{1}$} \\
\hline & Monensin & Control \\
\hline $\mathrm{n}$ & 18 & 19 \\
\hline \multicolumn{3}{|l|}{ Proportion of cows with } \\
\hline Two follicular waves/cycle, $\%(\mathrm{n})^{2}$ & $78.6(11)$ & $58.8(10)$ \\
\hline Three follicular waves/cycle, $\%(\mathrm{n})^{2}$ & $21.4(3)$ & $41.2(7)$ \\
\hline Follicular cysts (DIM 50 to 80 ), \% (n) & $22.2(4)$ & $15.8(3)$ \\
\hline Proportion of cows ovulating after PGF, \% (n) & $72.2(13)$ & $57.9(11)$ \\
\hline Time of ovulation after PGF, $\mathrm{h}^{3}$ & $92.46 \pm 3.6$ & $94.8 \pm 3.9$ \\
\hline Diameter of ovulating follicle after PGF, $\mathrm{mm}^{3}$ & $17.76 \pm 0.9$ & $20.3 \pm 51.0$ \\
\hline First AI pregnancy rate, $\%(n)$ & $27.8(5)$ & $31.6(6)$ \\
\hline
\end{tabular}

\footnotetext{
${ }^{1}$ Treatment values not different $(P>0.05)$.

${ }^{2}$ Proportions were determined only for cows that were cycling normally.

${ }^{3}$ Values are means $\pm \mathrm{SE}$. $\mathrm{PGF}=\mathrm{PGF}_{2 \alpha}$ analog.
}

opment of dominant follicles that either ovulated, regressed, or became cystic. The results indicate that monensin had no significant effects on either the development of the first dominant follicle or the number of class 1 to 3 follicles. These results are consistent with a previous study that showed that monensin had no effect on the diameter of the dominant and subordinate follicles or the number of small, medium, and large follicles in beef heifers (Reed and Whisnant, 2001). In contrast, Busmich et al. (1980) reported that in response to FSH and human chorionic gonadotropin treatment, beef heifers fed $200 \mathrm{mg}$ of monensin/d had higher number of follicles and ovulations than controls. Moreover, the heifers fed monensin had greater ovarian weights than the controls. In another study, monensinfed crossbred heifers induced to superovulate using FSH had greater number of small corpora lutea at ovariectomy than control animals (Harrison et al., 1982), indicating greater follicular development and ovulatory response.

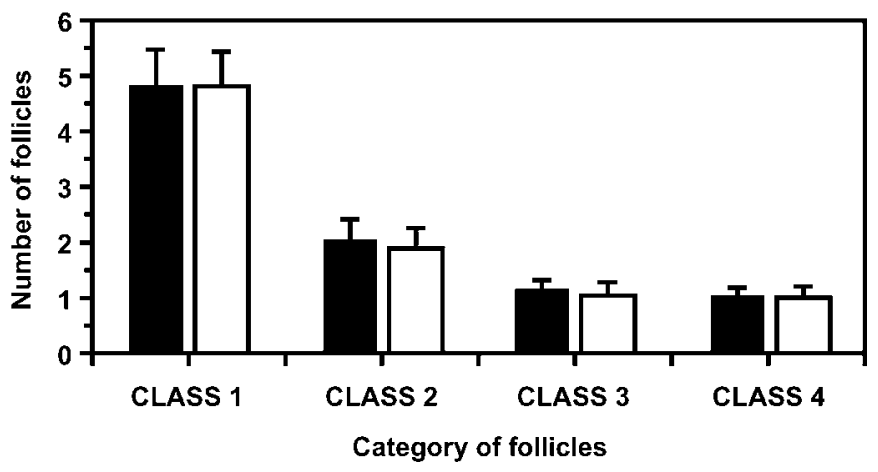

Figure 5. Mean ( \pm SE) number of class 1 to 4 follicles of cows fed monensin ( $\mathbf{\square})$ vs. control ( $\square$ ) cows during the last follicular wave of the breeding period. Effect of diet on number of follicles within all categories was not significant $(P>0.05)$.
The reduced number of class $4(>15 \mathrm{~mm})$ follicles observed on d 10 to 13 postpartum in monensin-fed cows in the current study may be indicative of earlier selection and the dominance of the ovulating follicle postpartum as confirmed by earlier first ovulation ( 5 d). There were no effects of monensin on the diameter of the first postpartum dominant and ovulating follicle. Whether the first postpartum dominant follicle ovulated, regressed, or became cystic was also not influenced by diet.

Although there were few differences between control and treated cows in postpartum ovarian follicles, the shorter postpartum interval to ovulation in monensinfed cows suggests earlier resumption of normal ovarian activity. Studies have shown that it is not the absence of follicular development that delays resumption of es-

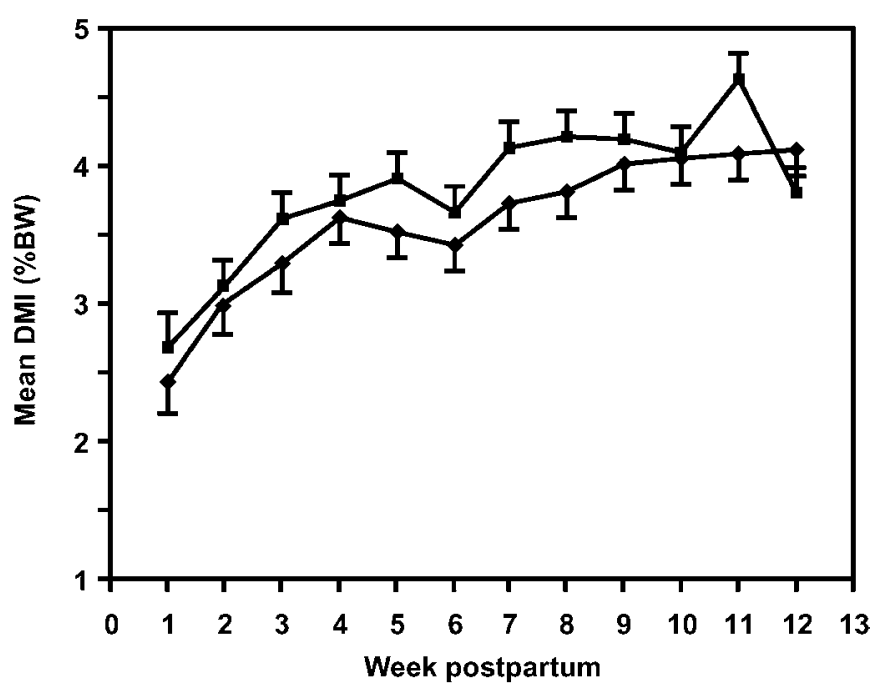

Figure 6. Mean $( \pm \mathrm{SE}) \mathrm{DMI}(\%$ of BW) of monensin $(\bullet)$ and control (ם) cows. Overall effect of diet on DMI (\% of BW) was not significant $(P>0.05)$. 
A

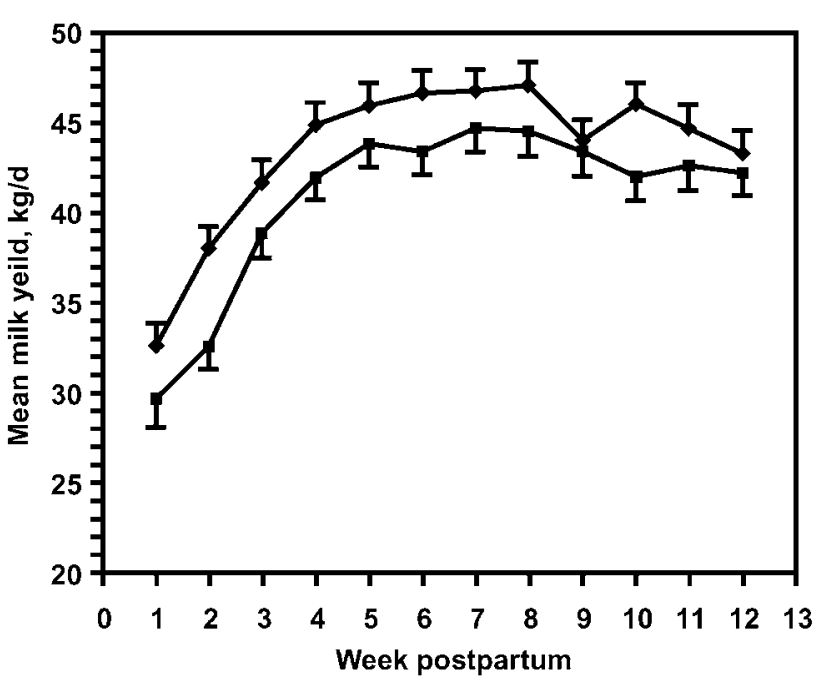

C

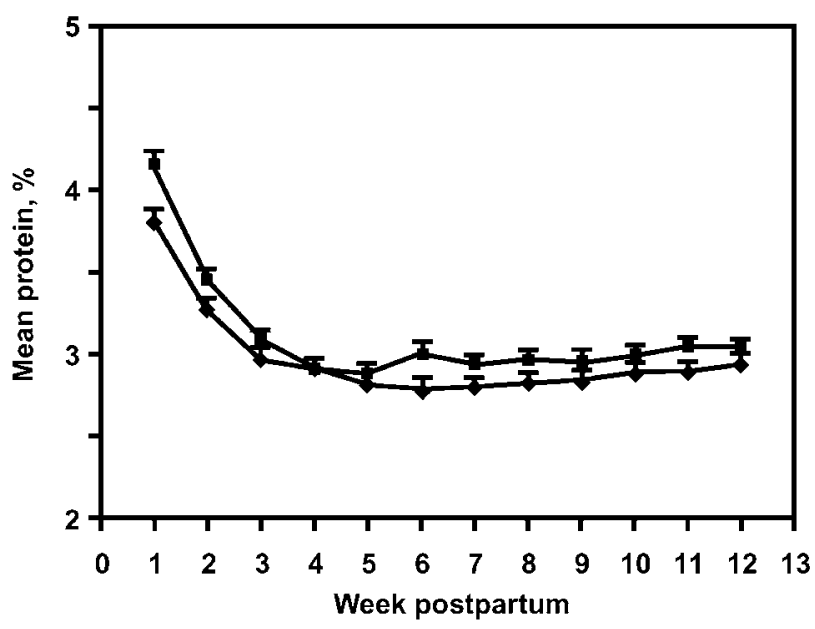

B

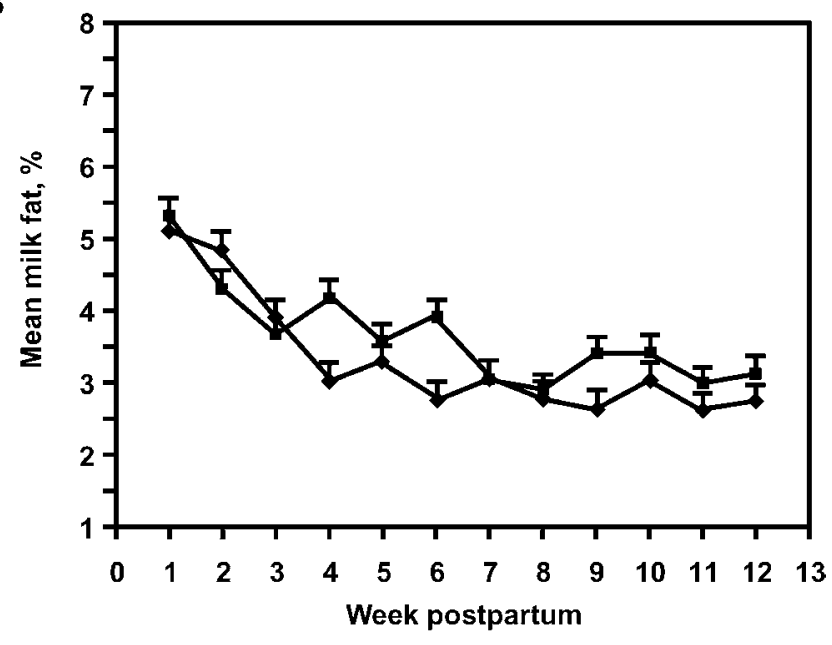

Figure 7. Panel A) mean ( \pm SE) milk yield $(\mathrm{kg} / \mathrm{d})$ for cows fed monensin $(\diamond)$ vs. control $(\mathbf{\square})$ cows. Overall effect of diet on milk yield was not significant $(P>0.05)$. Panel B) mean $( \pm \mathrm{SE})$ milk fat concentration $(\%)$ of cows fed monensin $(\bullet)$ vs. control $(\mathbf{\square})$ cows. Monensin reduced milk fat percentage $(P<0.05)$. Diet $\times$ week interaction was significant for milk fat percentage $(P<0.05)$. Panel C) mean $( \pm \mathrm{SE})$ milk protein concentration of monensin $(\diamond)$ and control $(\square)$ cows. Monensin reduced milk protein percentage $(P<0.05)$.

trous cyclicity, but rather the delay in resumption of normal episodic LH release that is needed for ovulation. Several studies suggest that the metabolic effects of monensin may have a positive influence on hypothala-

Table 4. Means ( \pm SE) of plasma BHBA, glucose, NEFA, and urea pooled for 10,17 , and 28 DIM.

\begin{tabular}{lcc}
\hline & \multicolumn{2}{c}{ Treatment } \\
\cline { 2 - 3 } Item & Monensin & Control \\
\hline $\mathrm{n}$ & 18 & 19 \\
$\mathrm{BHBA}, \mu \mathrm{mol} / \mathrm{L}$ & $684.8 \pm 54.3^{\mathrm{a}}$ & $1012.1 \pm 68.4^{\mathrm{b}}$ \\
Glucose, $\mathrm{mmol} / \mathrm{L}$ & $3.01 \pm 0.06$ & $2.83 \pm 0.06$ \\
$\mathrm{NEFA}, \mathrm{mEq} / \mathrm{L}$ & $0.42 \pm 0.04$ & $0.43 \pm 0.04$ \\
Urea, $\mathrm{mmol} / \mathrm{L}$ & $4.96 \pm 0.11$ & $5.05 \pm 0.11$ \\
\hline
\end{tabular}

${ }^{\mathrm{a}, \mathrm{b}}$ Treatment values different $(P<0.05)$. mic-pituitary function, resulting in accelerated ovarian recovery postpartum. Studies using prepubertal beef heifers indicate that monensin feeding increased $\mathrm{LH}$ release following $\mathrm{GnRH}$ challenge or estrogen administration (Randel and Rhodes, 1980; Randel et al., 1982). Hardin and Randel (1983) reported that monensin-fed beef cows had a delayed LH peak after an estradiol challenge. In addition to the delay in $\mathrm{LH}$ peak response following an FSH-induced estrus, monensin-fed heifers also had higher peak LH concentrations than the controls. It is not clear whether the monensin-induced changes in LH and FSH would alter ovarian follicular development. In contrast to our results, others have reported no effects of monensin on time of first ovulation (Abe et al., 1994) or estrus (Lean et al., 1994) in lactat- 
A

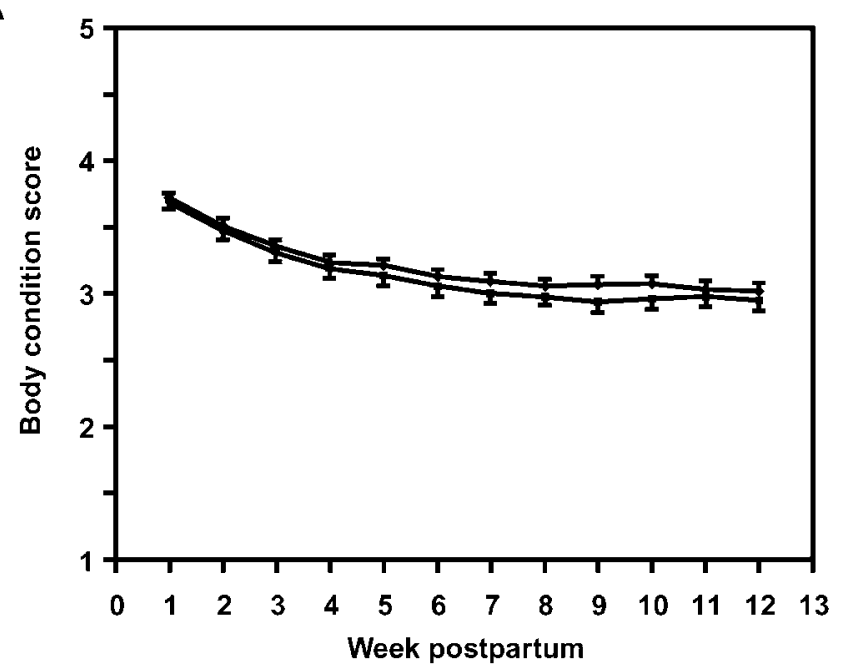

B

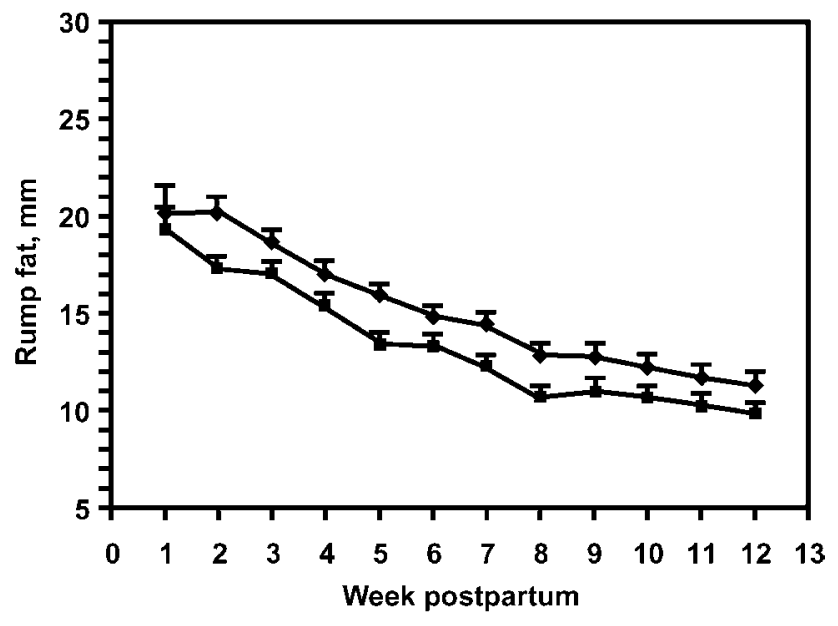

Figure 8. Panel A) mean ( \pm SE) BCS of monensin $(\bullet)$ and control $(\square)$ cows. Overall effect of diet on BCS was not significant $(P>0.05)$. Panel B) mean rump fat measurements of cows fed monensin ( ) vs. control ( $\boldsymbol{\square})$ cows. Overall effect of diet on rump fat was not significant $(P>0.05)$

ing dairy cows, despite increased plasma glucose concentrations and lower BHBA concentrations.

The monensin effect on LH release may be mediated through various metabolic signals. One of the effects of monensin feeding is the increased propionate:acetate production in the rumen (Richardson et al., 1976; Van Nevel and Demeyer, 1977; Bergen and Bates, 1984). Infusion of propionate into the rumen has been shown to enhance the secretion of $\mathrm{LH}$ in response to $\mathrm{GnRH}$ challenge in beef heifers (Rutter et al., 1983). Abomasal infusion of propionate in Brangus heifers resulted in higher peak $\mathrm{LH}$ and a greater area under the curve in response to $\mathrm{GnRH}$ challenge than controls infused with water. Increases in ruminal propionate induced by monensin should, therefore, have positive effects on LH release. Consistent with results of other studies (Sauer et al., 1989; Abe et al., 1994; Duffield et al., 1998), cows receiving monensin had lower BHBA concentrations. The failure to detect monensin effects on glucose concentrations is in agreement with some past reports (Stephenson et al., 1997) but may also reflect lack of statistical power to detect any difference. Other studies with more statistical power have reported an increase in plasma glucose concentration (Grings and Males, 1987; Abe et al., 1994; Duffield et al., 1998; Green et al., 1999).

Due to the high correlation between duration of negative energy balance and the interval from calving to first estrus and ovulation (Butler et al., 1981; Canfield et al., 1990), it has been argued that recovery toward a positive energy balance may signal resumption of normal ovarian activity. Sodium monensin has been shown to modify rumen fermentation and improve di- gestive efficiency in beef and dairy cows (Richardson et al., 1976; Schelling, 1984). This would have an impact not only in energy balance but also on mineral and protein metabolism. Given the increased plasma glucose concentrations (Abe et al., 1994; Duffield et al., 1998) and increased efficiency in energy metabolism in the rumen when cows are fed monensin, there is a possibility that feeding monensin to transition cows hastens their recovery to a positive energy balance. The earlier ovulation in the current study may, therefore, reflect an earlier recovery toward positive nutrient balance in monensin-fed cows. This could have resulted in an earlier increase in LH pulse frequency postpartum followed by first postpartum ovulation.

As pointed out by Abe et al. (1994), the increased glucose and lower BHBA concentrations resulting from monensin supplementation were not associated with earlier ovulation or estrus postpartum. This could indicate that the reported effects of monensin on these variables may be mediated by other metabolic factors that affect regulation of pulsatile $\mathrm{LH}$ secretion, and thus the resumption of normal ovarian function following parturition. The timing of monensin treatment may also explain differences in the results. Whereas Abe et al. (1994) used an intraruminal controlled-release capsule method of treatment introduced at calving to cows on pasture, the current study incorporated monensin in the TMR diet $3 \mathrm{wk}$ before anticipated calving. This could have resulted in earlier effects of monensin on metabolic variables and an increased opportunity to modify the pituitary-ovarian axis before calving. 
Reed and Whisnant (2001) reported that monensin feeding had varied effects on the number of follicular waves per estrous cycle in beef heifers, depending on the diet composition. In contrast, the current study showed that the proportion of 2- or 3-wave cows in monensinfed and control cows was not different, although the number of observations was low. Similarly, monensin feeding had no effect on ovulation response following $\mathrm{PGF}$-induced luteolysis or first AI pregnancy rates. This agrees with previous studies on dairy cows (Lean et al., 1994; Hayes et al., 1996; Beckett et al., 1998; Duffield et al., 1999a), which found no effects of monensin on first service conception rates. Earlier reports (Randel and Rhodes, 1980; Harrison et al., 1982; Hardin and Randel, 1983) indicated that beef cows and heifers receiving monensin had a delayed LH surge and higher peak LH concentrations. If, however, the time of $\mathrm{LH}$ peak and LH peak concentration following PGF were altered due to monensin-induced effects, treatment differences in the timing of ovulation would have been expected. The results of this study showed that treatments did not differ in time of ovulation relative to $\mathrm{PGF}$ (M, $92.4 \mathrm{~h} ; \mathrm{C}, 94.8 \mathrm{~h}$ ). The early timed AI at $72 \mathrm{~h}$ likely lowered the first AI pregnancy rate in both groups.

Sauer et al. (1989) reported lowered DMI and milk fat content in monensin-fed cows. In the current study, there were no monensin effects on DMI, although treated cows tended to have lower intakes. Van der Werf et al. (1998) also reported reduced feed intake in monensin-treated cows, but the effect was not statistically significant. Increased milk yield in monensin treatment cows was not detected, although this has been reported in previous studies (Beckett et al., 1998; Phipps et al., 2000). In agreement with the findings of previous studies (Sauer et al., 1989, 1998; Abe et al., 1994; Van der Werf et al., 1998; Phipps et al., 2000), monensin reduced milk fat concentrations. Milk protein content was also reduced in monensin-treated cows. However, the majority of previous studies (Abe et al., 1994; Duffield et al., 1999b; Vallimont et al., 2001) have reported no effect of monensin on milk protein concentrations and, in this study, the overall protein yield was not affected by monensin.

There was a significant effect of week postpartum on BCS and rump fat measurements. However, no diet effects on these two variables were observed. The high positive correlation between BCS and rump fat measurements show that the ultrasound rump fat measurements may be used as an objective indicator of body condition. The reports on the effects of monensin on BCS have been mixed, with some studies reporting no effect of monensin on BCS (Lean et al., 1994; Green et al., 1999). In contrast, other studies have reported reduced loss of BCS for monensin-treated cows (Duffield et al., 1998; Wagner et al., 1999). Due to the small sample size of the study, the lack of treatment differences in milk production, DMI, body condition measurements, and pregnancy rates may indicate the possibility that there was insufficient statistical power to detect differences.

\section{CONCLUSIONS}

Results from this study show that dietary monensin (22 $\mathrm{mg} / \mathrm{kg} \mathrm{DM}$ ) had no effect on development of the first dominant follicle postpartum, nor the number of ovarian follicles of all categories. The first ovulation postpartum occurred $5 \mathrm{~d}$ earlier in the monensin-fed cows than in the control group, with no diet effects on diameter of the ovulating follicle. Monensin did not alter the proportion of cows with 2 or 3 waves of ovarian follicular development per cycle nor the number of follicles of all classes during the breeding period. Similarly, the times of ovulation following $\mathrm{PGF}_{2 \alpha}$ administration and pregnancy rates after $\mathrm{AI}$ were not different between monensin and control groups. It is possible that diet effects on milk production, DMI, pregnancy rates, and other reproductive measures were not significant due to the insufficient statistical power of the study. The study suggests earlier resumption of normal ovarian follicular activity and ovulation for cows supplemented with monensin.

\section{ACKNOWLEDGMENTS}

The authors acknowledge financial support for this study from the Ontario Ministry of Agriculture and Food (OMAF) and Elanco Animal Health, Division Eli Lilly Canada, Inc. We thank the Ponsonby Dairy Research staff for their assistance in conducting the study.

\section{REFERENCES}

Abe, N., I. J. Lean, A. Rabiee, J. Porter, and C. Graham. 1994. Effects of sodium monensin on reproductive performance of dairy cattle. II. Effects on metabolites in plasma, resumption of ovarian cyclicity and oestrus in lactating cows. Aust. Vet. J. 71:277-281.

Beam, S. W., and W. R. Butler. 1998. Energy balance, metabolic hormones, and early postpartum follicular development in dairy cows fed prilled lipid. J. Dairy Sci. 81:121-131.

Beam, S. W., and W. R. Butler. 1999. Effects of energy balance on follicular development and first ovulation in postpartum dairy cows. J. Reprod. Fertil. 54(Suppl.):411-424.

Beckett, S., I. Lean, R. Dyson, W. Tranter, and L. Wade. 1998. Effects of monensin on the reproduction, health and milk production of dairy cows. J. Dairy Sci. 81:1563-1573.

Bushmich, S. L., R. D. Randel, M. M. McCartor, and L. H. Carroll. 1980. Effect of dietary monensin on ovarian response following gonadotropin treatment in prepuberal heifers. J. Anim. Sci. $51: 692-698$.

Butler, W. R., R. W. Everett, and C. E. Coppock. 1981. The relationship between energy balance, milk production and ovulation in postpartum Holstein cows. J. Anim. Sci. 53:742-748. 
Canfield, R. W., and W. R. Butler. 1990. Energy balance and pulse LH secretion in early postpartum dairy cattle. Domest. Anim. Endocrinol. 7:323-330.

Canfield, R. W., and W. R. Butler. 1991. Energy balance, first ovulation and the effects of naloxone on LH secretion in early postpartum dairy cows. J. Anim. Sci. 69:740-746.

Canfield, R. W., C. J. Sniffen, and W. R. Butler. 1990. Effects of excess degradable protein on postpartum reproduction and energy balance in dairy cattle. J. Dairy Sci. 73:2342-2349.

Duffield, T. F., K. E. Leslie, D. Sandals, K. Lissemore, B. W. McBride, J. H. Lumsden, P. Dick, and R. Bagg. 1998. Effect of prepartum administration of monensin in a controlled-release capsule on postpartum energy indicators in lactating dairy cows. J. Dairy Sci. 81:2354-2361.

Duffield, T. F., K. E. Leslie, D. Sandals, K. Lissemore, B. W. McBride, J. H. Lumsden, P. Dick, and R. Bagg. 1999a. Effect of a monensincontrolled release capsule on cow health and reproductive performance. J. Dairy Sci. 82:2377-2384.

Duffield, T. F., K. E. Leslie, D. Sandals, K. Lissemore, B. W. McBride, J. H. Lumsden, P. Dick, and R. Bagg. 1999b. Effect of prepartum administration of monensin in a monensin-controlled release capsule on milk production and milk components in early lactation. J. Dairy Sci. 82:272-279.

Edmonson, A. J., I. J. Lean, L. D. Weaver, T. Farver, and G. Webster. 1989. A body condition scoring chart for Holstein dairy cows. J. Dairy Sci. 72:68-78.

Gill, J. L., and H. D. Hafs. 1971. Analysis of repeated measurements of animals. J. Anim. Sci. 33:331-336.

Gowan E. W., and R. J. Etches. 1979. A solid-phase radioimmunoassay for progesterone and its application to pregnancy diagnosis in the cow. Theriogenology 12:327-344.

Grings, E. E., and J. R. Males. 1987. Performance, blood and ruminal characteristics of cows receiving monensin and a magnesium supplement. J. Anim. Sci. 66:566-573.

Hardin, D. R., and R. D. Randel. 1983. Effects of monensin on postpartum interval to first estrus and serum LH response to $0,1,2$ or $4 \mathrm{mg}$ estradiol- $17 \beta$ at 21 days postpartum. Theriogenology 19:343-354

Harrison, L. M., T. R. Hansen, and R. D. Randel. 1982. Evidence for seasonal and nutritional modification of ovarian and pituitary function in crossbred heifers and Brahman cows. J. Anim. Sci. 55:649-656.

Hayes, D. P., D. U. Pfeiffer, and N. B. Williamson. 1996. Effect of intraruminal monensin capsules on reproductive performance and milk production of dairy cows fed pasture. J. Dairy Sci. 79:1000-1008

Lamming, G. E., D. C. Wathes, and A. R. Peters. 1981. Endocrine patterns of post-partum cow. J. Reprod. Fertil.. 30(Suppl.):155170

Lean, I. J., M. Curtis, R. Dyson, and B. Lowe. 1994. Effects of sodium monensin on reproductive performance of dairy cattle. I. Effects on conception rates, calving-to conception intervals, calving-toheat and milk production in dairy cows. Aust. Vet. J. 71:273-277.

Lucy, M. C., C. R. Staples, F. M. Michel, and W. W. Thatcher. 1991. Energy balance and size of ovarian follicles detected by ultrasonography in early postpartum dairy cows. J. Dairy Sci. 74:473482.

Lucy, M. C., C. R. Staples, W. W. Thatcher, P. S. Erickson, R. M. Cleale, J. L. Firkins, M. R. Murphy, J. H. Clark, and B. O. Brodie. 1992. Influence of diet composition, dry matter intake, milk production, and energy balance on time of postpartum ovulation and fertility in dairy cows. Anim. Prod. 54:323-331.
Malven, P. V. 1984. Pathophysiology of the puerperium: Definition of the problem. Proc. of the 10th Int. Cong. on Anim. Reprod. and Artificial Insemination 4(III):1-8.

Meinert, R. A., M. J. Young, A. J. Heinrichs, and G. A. Varga. 1992. Effects of monensin on growth, reproductive performance and estimated body composition in Holstein heifers. J. Dairy Sci. 75:257-261.

Moseley, W. M., M. M. McCartor, and R. D. Randel. 1977. Effects of monensin on growth and reproductive performance of beef heifers. J. Anim. Sci. 45:961-965.

NRC. 1989. Nutrient Requirements of Dairy Cattle. 6th rev. ed. Natl. Acad. Press, Washington, DC.

Phipps, R. H., J. I. D. Wilkinson, L. J. Jonker, M. Tarrant, A. K. Jones, and A. Hodge. 2000. Effect of monensin on milk production of Holstein-Friesian dairy cows. J. Dairy Sci. 83:2789-2794.

Randel, R. D., and R. C. Rhodes. 1980. The effect of dietary monensin on the luteinizing hormone response of prepuberal heifers given a multiple gonadotropin-releasing hormone challenge. J. Anim. Sci. 51:925-931.

Randel, R. D., L. M. Rutter, and R. D. Rhodes. 1982. Effect of monensin on the estrogen-induced LH surge in prepuberal heifers. J. Anim. Sci. 54:806-810.

Reed, B. K., and C. S. Whisnant. 2001. Effects of monensin and forage:concentrate ratio on feed intake, endocrine, and ovarian function in beef heifers. Anim. Reprod. Sci. 67:171-180.

Richardson, L. F., A. P. Raun, E. L. Potter, C. O. Cooley, and R. P. Rathmacher. 1976. Effect of monensin on rumen fermentation in vitro and in vivo. J. Anim. Sci. 43:657-664.

Rutter, L. M., R. D. Randel, G. T. Schelling, and D. W. Forrest. 1983. Effect of abomasal infusion of propionate on the GnRH-induced luteinizing hormone release in prepuberal heifers. J. Anim. Sci. $56: 1167-1173$

Sauer, F. D., J. K. G. Kramer, and W. Cantwell. 1989. Antiketogenic effects of monensin in early lactation. J. Dairy Sci. 72:436-442.

Sauer, F. D., V. Fellner, R. Kinsman, J. K. G. Kramer, H. A. Jackson, A. J. Lee, and S. Chen. 1998. Methane output and lactation response in Holstein cattle with monensin or unsaturated fat added to the diet. J. Anim. Sci. 76:906-914.

Schelling, G. T. 1984. Monensin mode of action in the rumen. J. Anim Sci. 58:1518-1527.

Sirois, J., and J. E. Fortune. 1988. Ovarian follicular dynamics during the estrous cycle in heifers monitored by ultrasonography. Biol. Reprod. 39:308-317.

Stephenson, K. A., I. J. Lean, M. L. Hyde, M. A. Curtis, J. K. Garvin, and L. B. Lowe. 1997. Effects of monensin on the metabolism of periparturient dairy cows. J. Dairy Sci. 80:830-837.

Thatcher, W. W., and C. J. Wilcox. 1973. Postpartum estrus as an indicator of reproductive status in the dairy cow. J. Dairy Sci. $56: 608-610$

Vallimont, J. E., G. A. Varga, A. Arieli, T. W. Cassidy, and K. A. Cummins. 2001. Effects of prepartum somatotropin and monensin on metabolism and production of periparturient Holstein dairy cows. J. Dairy Sci. 84:2607-2621.

Van der Werf, J. H. J., L. J. Jonker, and J. K. Oldenbroek. 1998. Effects of monensin on milk production by Holstein and Jersey cows. J. Dairy Sci. 81:427-433.

Van Nevel, C. J., and D. I. Demeyer. 1977. Effect of monensin on rumen metabolism in vitro. Appl. Environ. Microbiol. 34:251-257.

Wagner, J. R., H. B. Green, J. T. Symanowski, J. I. D. Wilkinson, J. S. Davis, M. R. Himstedt, M. S. Allen, E. Block, J. J. Brennan, H. H. Head, J. J. Kennelly, J. N. Nielsen, J. E. Nocek, M. J. Van Der List, and L. W. Whitlow. 1999. Effect of monensin on feed intake, body weight and body condition in dairy cows. J. Dairy Sci. 82(Suppl. 1):75. (Abstr.) 